\title{
Heat and Mass Transfer and Thermo Physical Analysis of Water Distillation Using Passive Solar Still
}

\author{
M. Koilraj Gnanadason ${ }^{*}$, P. Senthil Kumar ${ }^{2}$, Vincent H. Wilson ${ }^{3}$ \\ ${ }^{1}$ Principal, Jayaraj Annapackiam CSI Polytechnic College, Nazareth, Tamil Nadu, India \\ ${ }^{2}$ Principal, K.S.R. College of Engineering, Tiruchengode, Tamil Nadu, India \\ ${ }^{3}$ Professor in Technology Management, Vellore Institute of Technology, Vellore, Tamil Nadu, India \\ Email: *koiljemil@yahoo.co.in
}

How to cite this paper: Gnanadason, M.K., Kumar, P.S. and Wilson, V.H. (2020) Heat and Mass Transfer and Thermo Physical Analysis of Water Distillation Using Passive Solar Still. Smart Grid and Renewable Energy, 11, 73-87. https://doi.org/10.4236/sgre.2020.116006

Received: June 1, 2020

Accepted: June 27, 2020

Published: June 30, 2020

Copyright ( 2020 by author(s) and Scientific Research Publishing Inc. This work is licensed under the Creative Commons Attribution International License (CC BY 4.0).

http://creativecommons.org/licenses/by/4.0/ (c) (i) Open Access

\begin{abstract}
The demand of fresh water is becoming an increasingly important issue across the world. To alleviate this problem, a single slope single basin solar still was designed and tested. Top glass cover $9^{\circ}$ slope ensures a very good transmission of solar radiation inside the still. In this paper a review of factors that improve the performance of the still is presented. Energy balances are made for each element of the still; solar time, direction of beam of radiation, clear sky radiation, optical properties of the cover, convection outside the still, convection and evaporation inside are accounted. Theoretical analysis of the heat and mass transfer mechanisms inside the solar still has been developed to find out heat transfer coefficients such as internal and external heat transfer modes and thermo physical properties such as dynamic viscosity, density, thermal conductivity, latent heat of evaporation and saturated vapor pressure for passive solar distillation system. Heat transfer coefficients were estimated for the present system since the still efficiency depends on heat transfer modes. It is also suggested that the water temperature plays a vital role in the distillate output since it increases significantly with the rise of basin water temperature. It is also found that the rise in water temperature increases the evaporative heat transfer coefficient value significantly.
\end{abstract}

\section{Keywords}

Solar Still, Ambient, Convection, Evaporation, Still Performance, Solar Energy

\section{Introduction}

In many areas of the world especially in developing countries, the shortage of 
drinking water for livelihood is an important problem. An immediate attention is required as the drinking water resources are being exploited and polluted rapidly by human beings [1]. The potable water is very scarce and the establishment of a human habitat in these areas strongly depends on how such water can be made available in arid regions. The importance of supplying potable water can hardly be over stressed [2]. Many techniques are available for purification of saline water among them solar still is simple and economical [3] [4]. Two major advantages favor the use of solar stills-clean and free energy and friendly to environment [5] [6]. Also the availability of clean water is a necessity for reducing the spread of diseases in these countries [7] [8]. Solar still is the widely used solar desalination device. Single slope solar still is the basic model of solar still and it is shown in Figure 1. The solar still at its lower part consists of basin which is insulated with insulating material to reduce the thermal losses to the surroundings. An inlet is provided for the access of saline water. Condensing covers are located on the top of the still. An outlet is provided to collect the distilled water [9].

\section{Parameters of Solar Still Influencing the Performance}

The solar still productivity and efficiency depends on the various parameters like solar radiation intensity, temperature, basin water depth, glass cover material thickness, and its inclination, wind velocity and the heat capacity of the still [9]. The parameters such as solar radiation intensity, temperature and wind velocity are uncontrolled as they are metrological parameters. Other parameters such as collector area, aperture ratio, water depth, glass thickness and insulation are controlled since they are managed by humans. Omar et al. [10] revealed that the productivity and efficiency of the solar still improves with increase in intensity. Also due to higher solar intensity the overall heat loss coefficient increases until it reaches the maximum. Kalidasa Murugavel et al. [11] suggested that the temperature difference between the water and glass is high, the productivity increases.

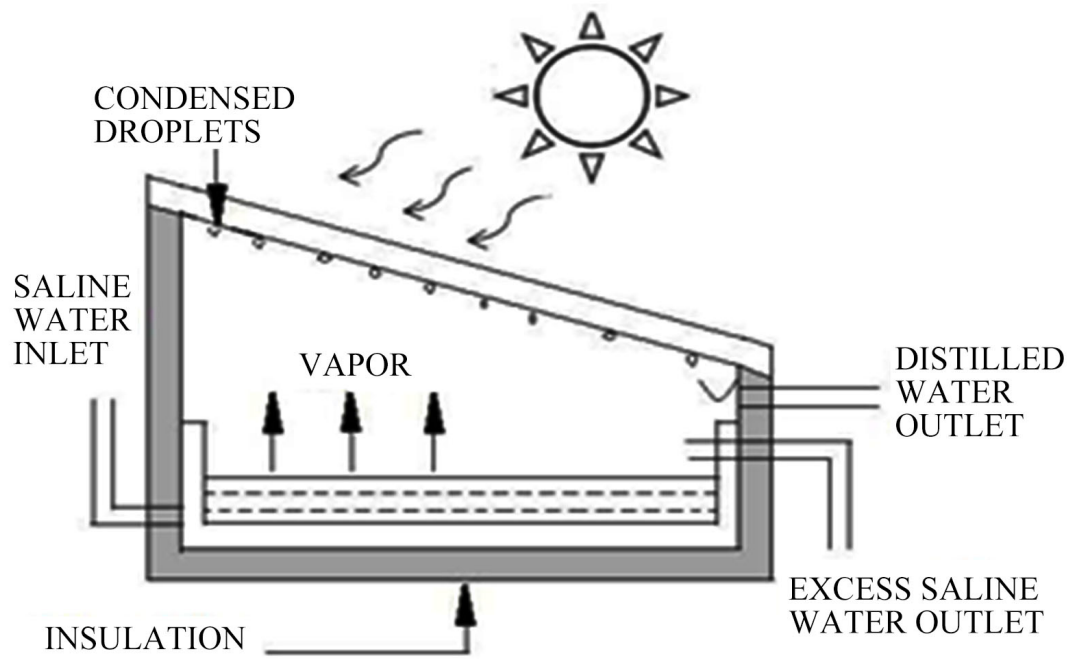

Figure 1. Skeleton of a single basin solar. 
Ahmed et al. [12] conducted experimental analysis on double slope solar still based on temperature and also verified its numerical results. The productivity is enhanced by increasing the temperature of water usingwater heater in the base of solar still [13] [14]. Velmurugan et al. [15] inferred that an increase in collector area results in more productivity. Bilal et al. [16] concluded that the productivity of the solar still decreases linearly with increase in depth of water at the rate of 0.4 lit./cm. and found that the optimum tilt angle for more production as $35^{\circ}$ during the month of May in Jordan, where the latitude angle is $31^{\circ}$. Singh and Tiwari [17] and Velmurugan et al. [18] found that the annual yield of the solar still is maximum when the condensing glass coverinclination is equal to the latitude of the place. Solar still with glass cover plate with $3 \mathrm{~mm}$ thickness gives $15.5 \%$ more production than the cover of $6 \mathrm{~mm}$ glass plate thickness [19].

\section{Experimental Setup}

A single basin solar still made up of Copper sheet was designed for the basin size of $900 \times 300 \times 50 \mathrm{~mm}$ and $2 \mathrm{~mm}$ thick as shown in Figure 2. The Copper has higher thermal conductivity and the rate of heat transfer to water in the still is more. The basin is enclosed in a wooden box of inner cross section $1050 \times 350 \times$ $430 \mathrm{~mm}$ and thickness $15 \mathrm{~mm}$. Plywood is used as outer cover to keep the still basin inside. The gap of $25 \mathrm{~mm}$ between the sides of the tray and the wooden box is filled with saw dust to prevent heat loss. Copper sheet was made in to a rectangular tray by sheet metal work of bending and cutting. The effective area of the solar still for saline water is $0.27 \mathrm{~m}^{2}$. The height of the solar still was taken $15 \mathrm{~cm}$ for lower end of glass. The glass of size $1175 \times 320 \mathrm{~mm}$ was used as the roof for the still. The top of the basin is covered with a $5 \mathrm{~mm}$ thick transparent glass of $\mathrm{mm}$. The cover is sealed tightly using silicon sealant to reduce the vapor leakage and the basin becomes air tight. The still is positioned in such a way that the sloping sides always face the sun. The whole experimental setup was kept in the North-South direction, with the inclination of $9^{\circ}$. The solar stills were properly oriented, and directly exposed to the solar radiation. The measured parameters and quantities were: the solar radiation intensity $(I)$, the glass temperature $\left(T_{g}\right)$, the basin water temperature $\left(T_{w}\right)$, and the ambient air temperature $\left(T_{a}\right)$.

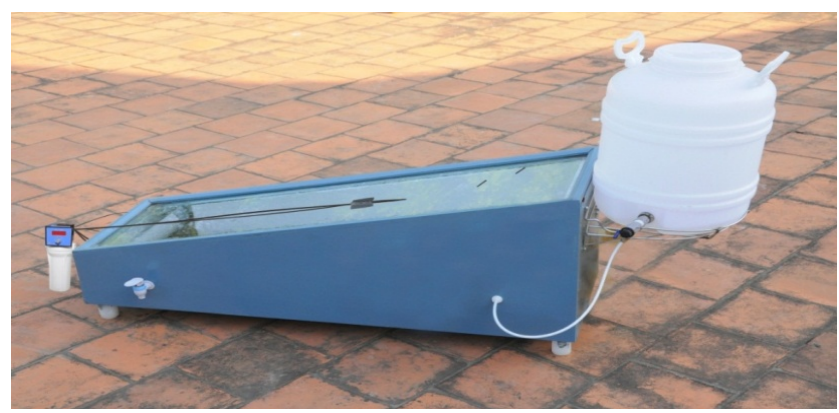

Figure 2. Solar still made up of copper. 


\section{Experimental Procedure}

The measurements of the solar intensity, wind velocity, ambient, glass inside, glass outside, vapor, water, basin temperature and distillate yield are taken hourly to study the effect of each parameter on the still productivity. The water level in the solar basin is maintained to a level of $1 \mathrm{~cm}$ for constant basin water mass of $2.7 \mathrm{~kg}$. Readings are taken at an interval of one hour till the sun sets in the evening. The solar intensity, wind velocity, wet bulb temperature, dry bulb temperature, basin plate temperature, basin water temperature, glass temperature, vapor temperature and distilled water productivity are measured every 1 hour. The same measurement process is repeated by varying the water level inside the solar still to $3 \mathrm{~cm}$ and $5 \mathrm{~cm}$.

\section{Heat Transfer}

The energy balance equations at various portions of the solar still [20] [21] are described as follows:

The rate of energy gained by the glass and the rate of energy gained from the water surface to the glass by radiation, convection and evaporation are equal to the rate of energy lost to air.

\subsection{Outside Surface of Glass Cover}

Rate of energy received from inner glass cover by conduction = Rate of energy lost to the ambient by convection and radiation

$$
\frac{K_{g}}{L_{g}}\left(T_{g i}-T_{g o}\right)=q_{r, g-a}+q_{c, g-a}
$$

Equation (1) for the energy balance equation of the outside surface glass cover becomes,

$$
\frac{K_{g}}{L_{g}}\left(T_{g i}-T_{g o}\right)=q_{r, g-a}\left(T_{g o}-T_{a}\right)
$$

By simplifying Equation (2), the glass outside temperature $T_{g o}$ is written as,

$$
T_{g o}=\frac{\frac{K_{g}}{L_{g}} T_{g i}+h_{t, g-a} T_{a}}{h_{t, g-a}+\frac{K_{g}}{L_{g}}}
$$

\subsection{Inner Surface of Glass Cover}

Rate of energy absorbed from solar radiation + Rate of energy received from water mass by convection, evaporation and radiation $=$ Rate of energy transferred to glass outside surface

$$
\alpha_{g} I(t)_{s}+q_{r, w-g}+q_{c, w-g}+q_{e, w-g}=\frac{K_{g}}{L_{g}}\left(T_{g i}-T_{g o}\right)
$$

Equation (3)-(4) for the energy balance equation of the inside surface of the glass becomes, 


$$
\alpha_{g} I(t)_{s}+h_{t, w-g}\left(T_{w}-T_{g i}\right)=\frac{K_{g}}{L_{g}}\left(T_{g i}-T_{g o}\right)
$$

By substituting Equation (3) into Equation (5), the temperature of the inside surface of the glass is written as,

$$
\alpha_{g} I(t)_{s}+h_{t, w-g}\left(T_{w}-T_{g i}\right)=\frac{K_{g}}{L_{g}}\left(T_{g i}-\frac{\frac{K_{g}}{L_{g}} T_{g i}+h_{t, g-a} T_{a}}{h_{t, g-a}+\frac{K_{g}}{L_{g}}}\right)
$$

By rearranging Equation (6),

$$
\alpha_{g} I(t)_{s}+h_{t, w-g}\left(T_{w}-T_{g i}\right)=U_{c, g-a}\left(T_{g i}-T_{a}\right)
$$

where $U_{c, g-a}=\frac{\frac{K_{g}}{L_{g}} h_{t, g-a}}{\frac{K_{g}}{L_{g}}+h_{t, g-a}}$

By simplifying the above equation, we get,

$$
T_{g i}=\frac{\alpha_{g} I(t)_{s}+h_{t, w-g} T_{w}+U_{c, g-a} T_{a}}{h_{t, w-g}+U_{c, g-a}}
$$

\subsection{Basin Liner}

Rate of energy absorbed from solar radiation + Rate of energy lost to water mass by convection $=$ Rate of energy lost to the ambient by conduction and convection

$$
\left(1-\alpha_{g}\right)\left(1-\alpha_{w}^{1}\right) I(t)_{s}=q_{w}+q_{b}
$$

Equation (9) becomes

$$
\alpha_{g}\left(1-\alpha_{g}\right)\left(1-\alpha_{w}^{1}\right) I(t)_{s}=h_{w}\left(T_{b}-T_{w}\right)+h_{w b}\left(T_{b}-T_{a}\right)
$$

After simplifying Equation (10), the basin temperature of the solar still is,

$$
T_{b}=\frac{\alpha_{-b} I(t)_{s}+h_{w} T_{w}+h_{b} T_{a}}{h_{w}+h_{b}}
$$

where $\alpha_{-b}=\alpha_{g}\left(1-\alpha_{g}\right)\left(1-\alpha_{w}\right)$

\subsection{Water Mass}

Rate of energy absorbed from solar radiation + Rate of energy received from basin liner by convection + Rate of energy received from external devices $=$ Rate of energy stored + Rate of energy lost to the glass inner surface by convection, evaporation and radiation

$$
\alpha_{w} I(t)_{s}+q_{w}+Q_{u}=(M C)_{w} \frac{\mathrm{d} t_{w}}{\mathrm{~d} t}+\left[q_{r, w-g}+q_{c, w-g}+q_{e, w-g}\right]
$$

The energy balance equation of the water mass in the solar still becomes, 


$$
\alpha_{w}\left(1-\alpha_{g}\right) I(t)_{s}+h_{w}\left(T_{b}-T_{w}\right)+Q_{u}=(M C)_{w} \frac{\mathrm{d} t_{w}}{\mathrm{~d} t} h_{t, w-g}\left(T_{w}-T_{g i}\right)
$$

By substituting values of $T_{g i}$ and $T_{b}$ from Equations (8) and (11) into Equation (13),

$$
\begin{aligned}
& Q_{u}+I(t)_{s} \alpha_{-b} \frac{h_{w}}{\left(h_{w}+h_{b}\right)}+\alpha_{w}+\alpha_{g} \frac{h_{t, w-g}}{\left(h_{t, w-g}+U_{c, g-a}\right)} \\
& =(M C)_{w} \frac{\mathrm{d} t_{w}}{\mathrm{~d} t}+\left[\frac{h_{t, w-g} U_{c, g-a}}{h_{t, w-g}+U_{c, g-a}}\left(T_{w}-T_{a}\right)\right]+\left[\frac{h_{w} h_{b}}{\left(h_{w}+h_{b}\right)}\left(T_{w}-T_{a}\right)\right] \\
& Q_{u}+(\alpha \tau)_{\text {eff }} I(t)_{s}=(M C)_{w} \frac{\mathrm{d} t_{w}}{\mathrm{~d} t}+\left(U_{t}-U_{b}\right)+\left(T_{w}-T_{a}\right)
\end{aligned}
$$

where $(\alpha \tau)_{\text {eff }}=\alpha_{-b} \frac{h_{w}}{\left(h_{w}+h_{b}\right)}+\alpha_{w}+\alpha_{g} \frac{h_{t, w-g}}{\left(h_{t, w-g}+U_{c, g-a}\right)}, U_{b}=\frac{h_{w} h_{b}}{\left(h_{w}+h_{b}\right)} \quad$ and $U_{t}=\frac{h_{t, w-g} U_{c, g-a}}{h_{t, w-g}+U_{c, g-a}}$

In the case of a passive solar still, additional thermal energy becomes zero, $Q_{u}=0$.

The above equations can be expressed in simplified form as follows:

$$
\frac{\mathrm{d} t_{w}}{\mathrm{~d} t}+a T_{w}=f(t)
$$

where, $a=\frac{U_{L S}}{M_{w} C_{w}}$ and $f(t)=\frac{\alpha_{e} I(t)_{s}+U_{L S} T_{a}}{M_{w} C_{w}}$

The following assumptions have been made to find the approximate analytical solution:

1) The time interval $\Delta t(0<t<\Delta t)$ is small;

2) The value of " $a$ " is constant during the time interval $\Delta t$;

3) The function " $f(t)$ " is constant for the time interval between 0 and $t$;

4) i.e. $\overline{f(t)}=f(t)$.

By using the boundary condition, $T_{w(t=0)}=T_{w 0}$, the solution for above first order differential equation is

$$
T_{w}=\frac{\overline{f(t)}}{a}\left[1-\mathrm{e}^{-a t}\right]+T_{w o} c
$$

The hourly yield is given as follows,

$$
m_{e w}=\frac{h_{e, w-g}\left(T_{w}-T_{g i}\right)}{L} \times 3600 \times A_{s}
$$

The total daily yield is given as follows,

$$
M_{e w}=\sum_{i=1}^{24} m_{e w}
$$

\subsection{Overall Thermal Efficiency of the Olar Still}

The instantaneous thermal efficiency is calculated as 


$$
\eta_{i}=\frac{q_{e w}}{I(t)_{s}}
$$

The overall thermal efficiency of passive solar still is

$$
\eta_{\text {passive }}=\frac{\sum m_{e w} \times L}{\sum I(t)_{s} \times A_{s} \times 3600}
$$

where, $m_{e w}=$ mass of distillate collected in $\mathrm{kg} / \mathrm{h} ; A=$ Area of the basin in $\mathrm{m}^{2}$; $I(t)=$ Solar radiation with respect to time $\mathrm{W} / \mathrm{m}^{2}$; and $L=$ Latent heat of vaporization in $\mathrm{kJ} / \mathrm{kg}$.

\section{Results and Discussion}

The experimental study on single basin single slope passive solar still with black coated copper sheet is conducted at Nazareth, Tamil Nadu, India (Latitude: $9^{\circ} \mathrm{N}$; Longitude: $78^{\circ} \mathrm{E}$ and an altitude of $9 \mathrm{~m}$ above sea level). Experiments are carried out from 7:00 h to 17:00 h during clear sunny days. During the experiments, hourly variation of solar intensity, wind velocity, ambient, glass inside, glass outside, vapor, water, basin temperature and distillate yield are recorded. The average solar radiation is $755 \mathrm{~W} / \mathrm{m}^{2}$. It has been observed that solar radiation varies parabolically with time, with its maximum value at $13.00 \mathrm{~h}$. In the morning, the temperature of water is low; therefore it needs high energy to change its phase from saturated liquid to saturated vapor phase. The ambient temperature reached the minimum value in the early morning and it is gradually increased after sun rise. The results show that temperature and required heat are inversely proportional. In the early afternoon the temperature of water reaches the maximum so it needs less heat to vaporize and vice versa in the late afternoon. The average wind velocity on test day was $3 \mathrm{~m} / \mathrm{sec}$. The wind velocity is an important parameter which affects the glass outside temperature of the solar still due to which condensation at higher rate is attained and ultimately it is expected to give higher yield.

The hourly variation of measured parameters such as ambient temperature, basin, water temperature, vapour temperature, glass inside temperature and glass outside temperature are shown in Figure 3. The maximum water temperature of $77^{\circ} \mathrm{C}$ and glass inside temperature of $70^{\circ} \mathrm{C}$ was observed at $14: 00 \mathrm{~h}$.

The hourly variation of yield is shown in Figure 4. Copper has higher thermal conductivity and coating of black paint absorbs all the incident radiation so that the basin water temperature is increased and hence the increased in the evaporation rate. It was found that the higher distilled water yield was obtained with higher basin water temperature. It revealed that there is proportionality increase in distilled water production with respect to the basin water temperature.

Figure 5 shows the yield of solar stills in summer and winter for the PSS-Cu, B. It is observed that the maximum yields of $0.19 \mathrm{~kg}$ for the PSS-Cu, B was obtained at 13:00 $\mathrm{h}$ during the summer. This was due to the higher water temperatures in the basin of the solar still which increases the evaporation rate and in turn increases yield. It also shows that maximum yield of $0.13 \mathrm{~kg}$ for the PSS-Cu, $\mathrm{B}$ at 12:00-13:00 h during the winter. Daily climatic conditions have resulted in 
slight variations in water evaporation rates under low radiation conditions. By comparing the operation of the solar stills in the summer and winter, lower yield was observed for the solar still during the winter as a result of lower radiation and ambient temperatures. However, the percentage increase in yield was as high as it was during the summer. This can be attributed to less thermal losses under low temperature operating conditions resulting in an increase in yield.

Figure 6 shows the comparison of convective heat transfer coefficient in summer and winter. The convective heat transfer coefficient is not varied drastically and it is dependent on wind velocity. The maximum convective heat transfer coefficients of $2.91 \mathrm{~W} / \mathrm{m}^{2} \mathrm{~K}$ and $2.41 \mathrm{~W} / \mathrm{m}^{2} \mathrm{~K}$ for the PSS-Cu, B were obtained for the summer and winter respectively. The convective heat transfer coefficient is PSS-Cu, B is lower due to the vacuum present inside the solar still. The temperature difference between $(\Delta \mathrm{T})$ evaporative surface (water) and condensing surface (glass inside surface), which plays significant role in raising the yield and in evaporative heat transfer coefficient as well.

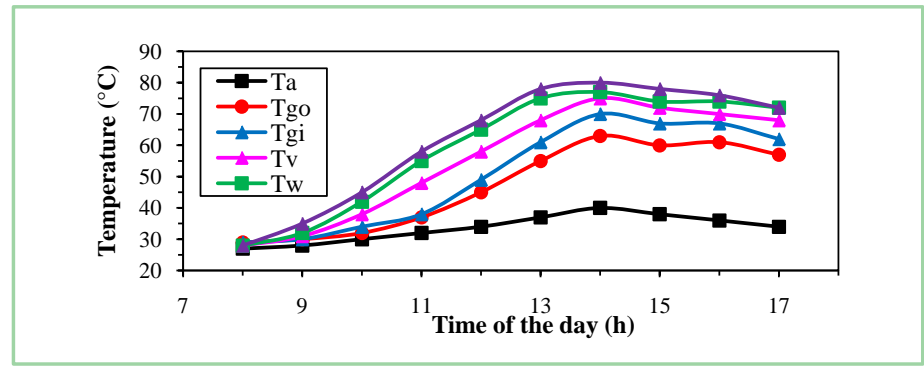

Figure 3. Hourly variation of different temperature.

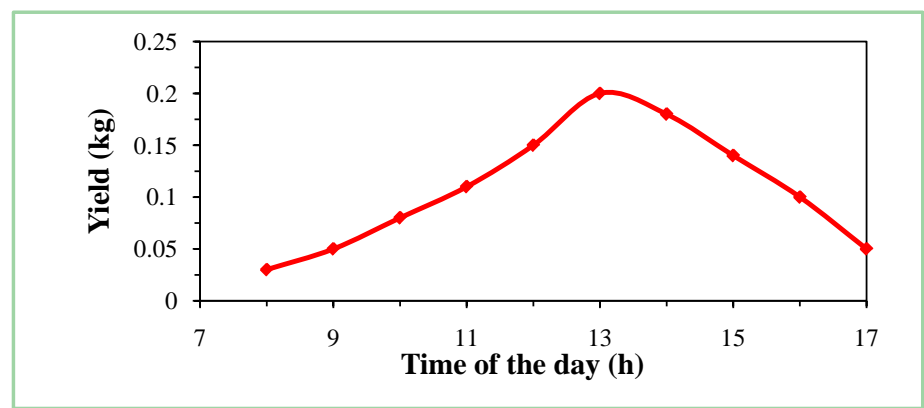

Figure 4. Hourly variation of hourly yield.

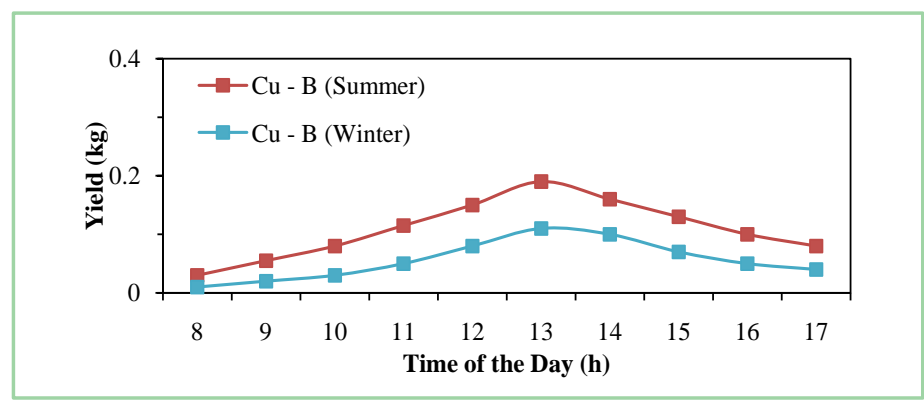

Figure 5. Comparison of hourly yield in summer and winter. 


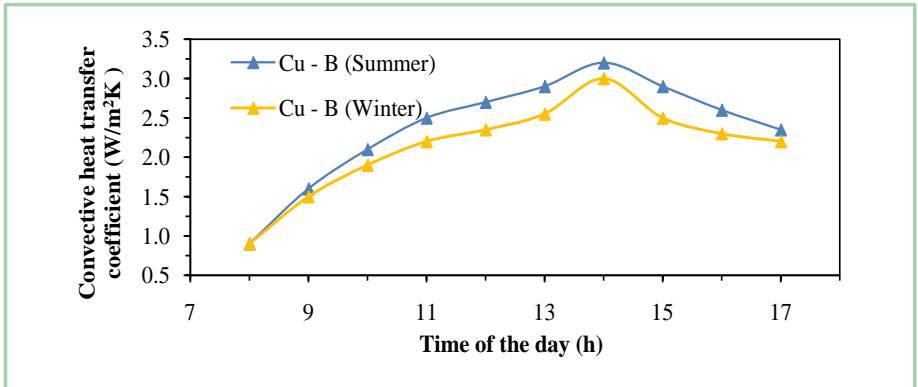

Figure 6. Convective heat transfer coefficient in summer and winter.

Figure 7 shows the comparison of evaporative heat transfer coefficient in summer and winter. The evaporative heat transfer coefficient increases with time and reaches a maximum at 14:00 $\mathrm{h}$ during the summer and 15:00 $\mathrm{h}$ during the winter prior to decreasing with time. The maximum value of the evaporative heat transfer coefficient measured during the summer and the winter was 75.13 $\mathrm{W} / \mathrm{m}^{2} \mathrm{~K}$ and $42.52 \mathrm{~W} / \mathrm{m}^{2} \mathrm{~K}$ respectively. The evaporative heat transfer coefficient is much higher than the convective and radiative heat transfer coefficients. The evaporative heat transfer coefficient is temperature dependent and is higher in the summer due to higher water temperature in the basin and lower in the winter. This is due to the higher thermal conductivity of copper sheet.

Figure 8 shows the comparison of radiative heat transfer coefficient in summer and winter. The radiative heat transfer coefficient did not vary much compared to the evaporative heat transfer coefficient and it was independent of temperature under normal operating conditions $\left(<80^{\circ} \mathrm{C}\right)$. The maximum radiative heat transfer coefficients of $7.96 \mathrm{~W} / \mathrm{m}^{2} \mathrm{~K}$ and $6.91 \mathrm{~W} / \mathrm{m}^{2} \mathrm{~K}$ were measured during the summer and winter respectively. Further it is also noticed that the convective and radiative heat transfer coefficients remain independent of the operating temperature.

Figure 9 shows the comparison of total heat transfer coefficient insummer and winter. The maximum total heat transfer coefficients were $110.62 \mathrm{~W} / \mathrm{m}^{2} \mathrm{~K}$ and $65.43 \mathrm{~W} / \mathrm{m}^{2} \mathrm{~K}$ in the summer and winter respectively, which can be attributed to the higher operating water temperature in the basin. The total heat transfer coefficient was much lower. The maximum values of total heat transfer coefficient $85.01 \mathrm{~W} / \mathrm{m}^{2} \mathrm{~K}$ and $52.10 \mathrm{~W} / \mathrm{m}^{2} \mathrm{~K}$ in the summer and winter respectively.

Figure 10 shows the hourly variation of the convective, radiative, evaporative and total heat transfer coefficients. It also shows that the evaporative and total heat transfer coefficients were much higher than the convective and radiative heat transfer coefficients. The evaporative heat transfer coefficient increased with time until 14:00 $\mathrm{h}$ and then its value decreased with time. The maximum values of the total and evaporative heat transfer coefficients were $58.6 \mathrm{~W} / \mathrm{m}^{2} \mathrm{~K}$ and $50.4 \mathrm{~W} / \mathrm{m}^{2}$ $\mathrm{K}$ respectively. The higher value of the total and evaporative heat transfer coefficients are due to the increase in the basin water temperature. The convective heat transfer coefficient did not vary much and mainly depended on the wind velocity.

The maximum thermal efficiencies achieved by passive solar still with black coated copper solar still is $40 \%$ as shown in Figure 11 and 22\% for the summer 
and winter respectively. The yield of the still was higher when compared to the still made up of galvanised iron sheet in both the summer and winter.

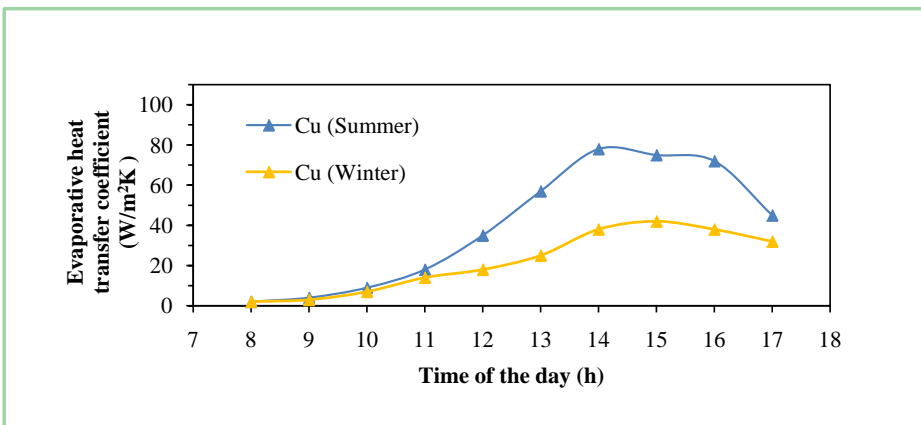

Figure 7. Evaporative heat transfer coefficient in summer and winter.

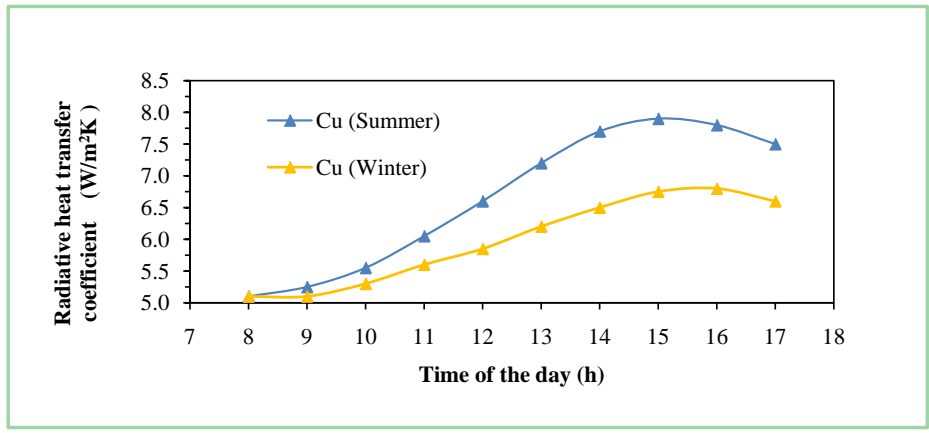

Figure 8. Radiative heat transfer coefficient in summer and winter.

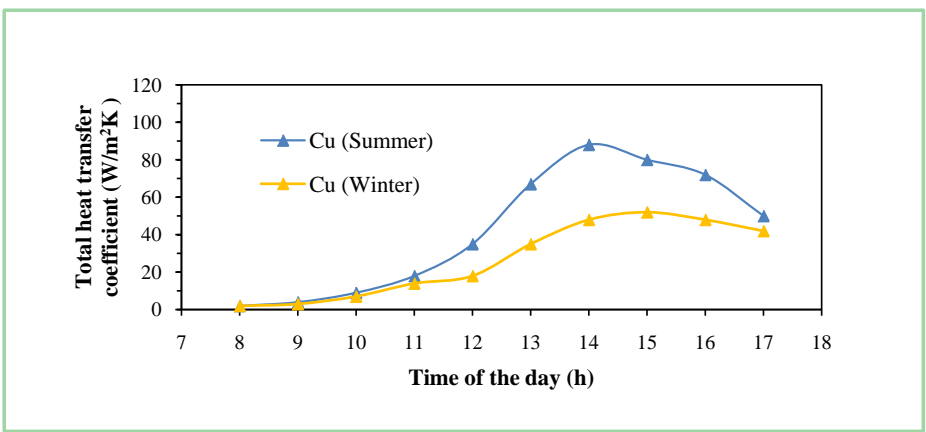

Figure 9. Total heat transfer coefficient in summer and winter.

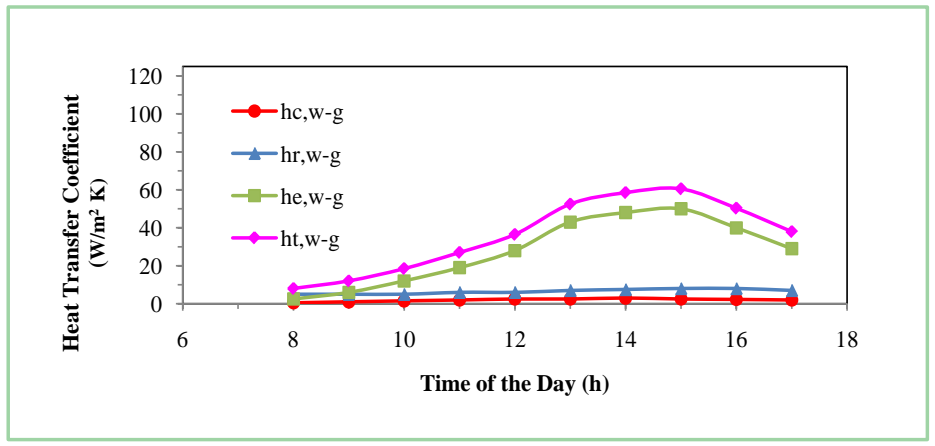

Figure 10. Hourly variation of heat transfer coefficients. 


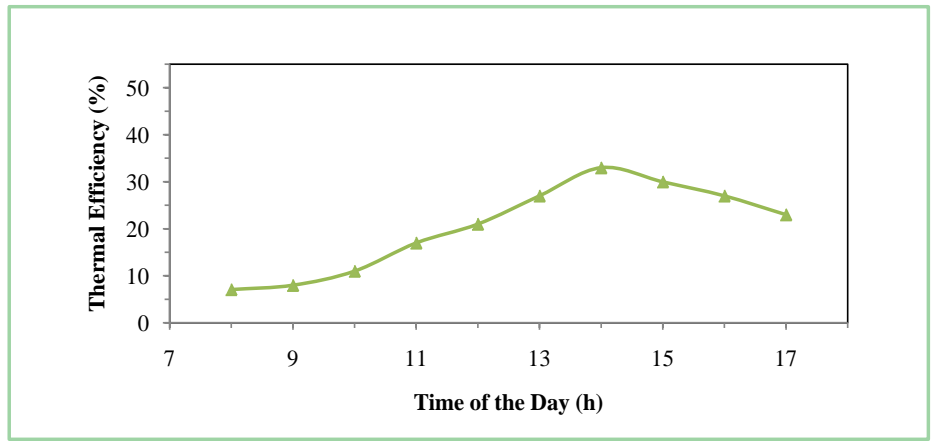

Figure 11. Hourly variation of the thermal efficiency.

\section{Conclusion}

The performance of single basin passive solar still is analysed on normal sunny days. The radiative heat transfer $\left(Q_{r}\right)$, convective heat transfer $\left(Q_{c}\right)$ and evaporative heat transfer $\left(Q_{e}\right)$ for internal and external heat transfer rates inside the still are predicted. The instantaneous efficiency and overall efficiency are calculated for all the studies. Heat transfer coefficients predicted under internal and external heat transfer modes for still performance. The thermal conductivity and dynamic viscosity increase with respect to time and possess almost the same trend. The variation of density of water is found for the still under these experiments and it is observed as 1.094133 to $1.1025812 \mathrm{~kg} \cdot \mathrm{m}^{-3}$. It is observed that the density decreases with respect to increase in water temperature and it starts to increase with the decrease in water temperature. The amount of daily distillate yield collected is $1.09 \mathrm{~kg} /$ day. The instantaneous efficiency is increased according to the time.

\section{Acknowledgements}

We would like to acknowledge our sincere thanks to the management of our colleges, our Colleagues and our family members who have supported and helped us different stages of this Research work.

\section{Conflicts of Interest}

The authors declare no conflicts of interest regarding the publication of this paper.

\section{References}

[1] Sampathkumar, K., Senthil Kumar, P. and Pitchandi, P. (2008) Performance of a Pyramid Solar Still. International Conference on Fascinating, Advancement in Mechanical Engineering, 1, 11-13.

[2] Arunkumar, T., Jayaprakash, R., Prakash, A., Suneesh, P.U., Karthik, M. and Kumar, S. (2016) Study of Thermo Physical Properties and an Improvement in Production of Distillate Yield in Pyramid Solar Still with Boosting Mirror. Indian Journal of Science and Technology, 3, 879-883. https://doi.org/10.17485/ijst/2010/v3i8.22 
[3] Omri, A., Orfi, J. and Nasrallah, S.B. (2005) Natural Convection Effects in Solar Stills. Desalination, 173, 29-42. https://doi.org/10.1016/j.desal.2005.04.025

[4] Velmurugan, V., Pandiarajan, P., Guruparan, P., Harihara Subramanian, L., David Prabaharan, C. and Srithar, K. (2009) Integrated Performance of Stepped and Single Basin Solar Stills with Mini Solar Pond. Desalination, 249, 902-909. https://doi.org/10.1016/j.desal.2009.06.070

[5] KoilrajGnanadason, M., Senthil Kumar, P., Wilson, V.H. and Kumaravel, A. (2013) Comparison between Performance Analyses between Single Basin Solar Still with and without Use of Vacuum. International Review of Mechanical Engineering (IREME), 7, 1495-1506.

[6] Harris Samuel, D.G., Nagarajan, P.K., Sathyamurthy, R., Agouz, S.A.El. and Kannan, E. (2016) Improving the Yield of Fresh Water in Conventional Solar Still Using Low Cost Energy Storage Material. Energy Convention \& Management, 112, 125-134. https://doi.org/10.1016/j.enconman.2015.12.074

[7] Panchal, H.N. (2013) Enhancement of Distillate Output of Double Basin Solar Still with Vacuum Tubes. Journal of King Saud University-Engineering Sciences, 27, 170-175. https://doi.org/10.1016/j.jksues.2013.06.007

[8] Phillips Agboola, O., Al-mutaz, I.S., Orfi, J. and Egelioglu, F. (2014) Economic Investigation of Different Configurations of Inclined Water Desalination Systems. Advances in Mechanical Engineering, 2014, Article ID: 925976. https://doi.org/10.1155/2014/925976

[9] KoilrajGnanadason, M., Senthil Kumar, P., Wilson, V.H. and Kumaravel, A. (2014) Productivity Enhancement of a Single Basin Solar Still. Desalination and Water Treatment (TDWT), 55, 1998-2008. https://doi.org/10.1080/19443994.2014.930701

[10] Badran, O.O. and Abu-Khader, M.M. (2007) Evaluating Thermal Performance of a Single Slope Solar Still. Heat and Mass Transfer, 43, 985-995.

https://doi.org/10.1007/s00231-006-0180-0

[11] Kalidasa Murugavel, K., Chockalingam, Kn.K.S.K. and Srithar, K. (2009) Modeling and Verification of Double Slope Single Basin Solar Still Using Laboratory and Actual Solar Conditions. Jordan Journal of Mechanical and Industrial Engineering, 3, 40-51.

[12] AlGarni, A.Z. (2012) Enhancing the Solar Still Using Immersion Type Water Heater Productivity and the Effect of External Cooling Fan in Winter. Applied Solar Energy, 48, 193-200. https://doi.org/10.3103/S0003701X12030048

[13] Alaudeen, A., Johnson, K., Ganasundar, P., Syed Abuthahir, A. and Srithar, K. (2013) Study on Stepped Type Basin in a Solar Still. Journal of King Saud University-Engineering Sciences, 26, 176-183. https://doi.org/10.1016/j.jksues.2013.05.002

[14] Phadatare, M.K. and Verma, S.K. (2007) Influence of Water Depth on Internal Heat and Mass Transfer in a Plastic Solar Still. Desalination, 217, 267-275. https://doi.org/10.1016/j.desal.2007.03.006

[15] Velmurugan, V. and Srithar, K. (2011) Performance Analysis of Solar Stills Based on Various Factors Affecting the Productivity-A Review. Renewable and Sustainable Energy Reviews, 15, 1294-1304. https://doi.org/10.1016/j.rser.2010.10.012

[16] Akash, B.A., Mohsen, M.S. and Nayfeh, W. (2000) Experimental Study of the Basin Type Solar Still under Local Climate Conditions. Energy Conversion \& Management, 41, 883-890. https://doi.org/10.1016/S0196-8904(99)00158-2

[17] Singh, H.N. and Tiwari, G.N. (2004) Monthly Performance of Passive and Active Solar Stills for Different Indian Climatic Conditions. Desalination, 168, 145-150. https://doi.org/10.1016/j.desal.2004.06.180 
[18] Velmurugan, V., Deenadayalan, C.K., Vinod, H. and Srithar, K. (2008) Desalination of Effluent Using Fin Type Solar Still. Energy, 33, 1719-1727.

https://doi.org/10.1016/j.energy.2008.07.001

[19] Ghoneyem, A. and Ariffleri (1997) Software to Analyze Solar Stills and an Experimental Study on the Effects of the Cover. Desalination, 114, 37-44.

https://doi.org/10.1016/S0011-9164(97)00152-5

[20] Omar Badran, O. (2011) Theoretical Analysis of Solar Distillation Using Active Solar Still. International Journal of Thermal \& Environmental Engineering, 3, 113-120. https://doi.org/10.5383/ijtee.03.02.009

[21] Tripathi, R. and Tiwari, G.N. (2006) Thermal Modelling of Passive and Active Solar Stills for Different Depths of Water by Using the Concept of Solar Fraction. Solar Energy, 80, 956-967. https://doi.org/10.1016/j.solener.2005.08.002 


\section{Nomenclature}

A: area, $\mathrm{m}^{2}$

$C p$ : specific heat, $\mathrm{J} / \mathrm{kgK}$

$I(t)$ : solar intensity on an inclined surface, $\mathrm{W} / \mathrm{m}^{2}$

$I_{d}$. diffuse radiation on a horizontal surface, $\mathrm{W} / \mathrm{m}^{2}$

$I_{g}$ : global radiation on a horizontal surface, $\mathrm{W} / \mathrm{m}^{2}$

$p$ : partial pressure, $\mathrm{N} / \mathrm{m}^{2}$

$Q$. heat transfer rate, $\mathrm{W}$

$q$ : heat flux, $\mathrm{W} / \mathrm{m}^{2}$

T: temperature, ${ }^{\circ} \mathrm{C}$

$d t$ time interval, $\mathrm{s}$

$d T$ : temperature difference, ${ }^{\circ} \mathrm{C}$

$h$ : heat transfer co-efficient, $\mathrm{W} / \mathrm{mK}$

$h_{f g}$ : enthalpy of evaporation at $T_{m} \mathrm{~J} / \mathrm{kg}$

$m_{c}:$ condensate, $\mathrm{kg} / \mathrm{hr}$

m: mass, $\mathrm{kg} / \mathrm{s}$

$U$ : side heat loss co-efficient from basin to ambient, $\mathrm{W} / \mathrm{m}^{2} \mathrm{~K}$

$V:$ wind velocity, $\mathrm{m} / \mathrm{s}$

$K$ : thermal conductivity, $\mathrm{W} / \mathrm{mK}$

$L$ : latent heat of vaporization, $\mathrm{kJ} / \mathrm{kg}$

$h_{c b}$ : basin liner convection heat transfer coefficient, $\mathrm{W} / \mathrm{m}^{2} \mathrm{~K}$

$h_{b}$ : basin liner overall heat transfer coefficient, $\mathrm{W} / \mathrm{m}^{2} \mathrm{~K}$

$h_{c g}$ : glass cover convection heat transfer coefficient, $\mathrm{W} / \mathrm{m}^{2} \mathrm{~K}$

$h_{c W}$ convective heat loss coefficient from water surface, $\mathrm{W} / \mathrm{m}^{2} \mathrm{~K}$

$h_{e w}$ : heat loss coefficient by evaporation from water, $\mathrm{W} / \mathrm{m}^{2} \mathrm{~K}$

$h_{r b}$ : basin liner radiative heat transfer coefficient, $\mathrm{W} / \mathrm{m}^{2} \mathrm{~K}$

$h_{r g}$ : glass cover radiative heat transfer coefficient, $\mathrm{W} / \mathrm{m}^{2} \mathrm{~K}$

$h_{r w}:$ basin water radiative heat transfer coefficient, $\mathrm{W} / \mathrm{m}^{2} \mathrm{~K}$

$h_{t g}$ : total glass heat transfer loss coefficient, $\mathrm{W} / \mathrm{m}^{2} \mathrm{~K}$

$h_{w}$ : convective heat transfer coefficient from basin to water $\mathrm{W} / \mathrm{m}^{2} \mathrm{~K}$

$h_{t w:}$ total water surface heat transfer loss coefficient, $\mathrm{W} / \mathrm{m}^{2} \mathrm{~K}$

$k_{\text {ins: }}$ insulation thermal conductivity, $\mathrm{W} / \mathrm{mK}$

$L_{\text {ins: }}$ insulation thickness, $\mathrm{m}$

$M$ : total mass productivity/day, $\mathrm{kg} /$ day

$M C_{w}$ : water heat capacity rate of water per unit area, $\mathrm{J} / \mathrm{m}^{2} \mathrm{~K}$

$P_{g}$ : glass saturated partial pressure, $\mathrm{N} / \mathrm{m}^{2}$

$P_{w}:$ water saturated partial pressure, $\mathrm{N} / \mathrm{m}^{2}$

$q_{g}:$ rate of total energy from the glass cover, $\mathrm{W} / \mathrm{m}^{2}$

\section{Subscripts}

a: ambient

b: basin

c. convective 
e. evaporative

g. glass

$r$ radiative

$w$. water

eq: equivalent loss side loss

d: daily

$t$ time

\section{Symbols}

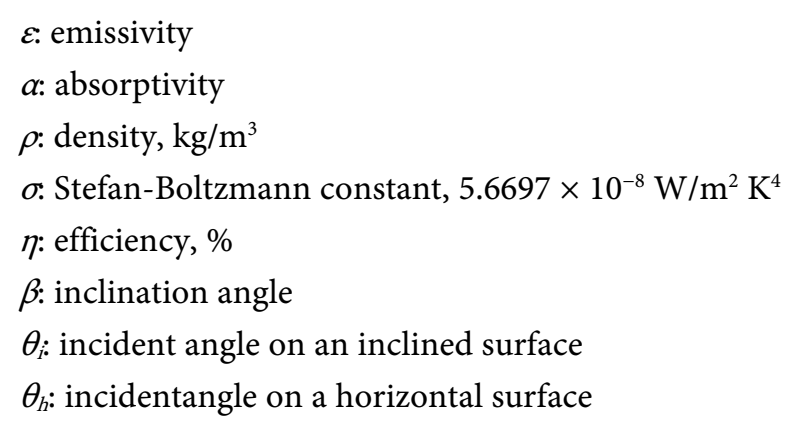

